Estudios de

lingüística inglesa aplicada

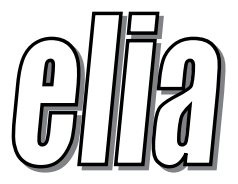

\title{
BILINGUAL EDUCATION RESEARCH: A BIBLIOMETRIC STUDY
}

\section{LA INVESTIGACIÓN EN EDUCACIÓN BILINGÜE: UN ESTUDIO BIBLIOMÉTRICO}

\section{Joan Aleixandre Agulló}

Universitat de València, Spain

ajo7@alumni.uv.es

\section{Enrique Cerezo Herrero}

Universitat Politècnica de València, Spain

ecerher@upv.es

DOI: http://dx.doi.org/10.12795/elia.mon.2019.i1.13

The aim of this paper is to analyze through bibliometric indicators the scientific literature related to bilingual education published between 1968 and September 2018. Bilingual education is shaping current educational systems all around the world. Bilingualism is thus a latent phenomenon in today's society and the number of educational practices including at least two languages in the teaching process is on the increase. Hence, the need to conduct a study with the objective of knowing where we stand as far as research is concerned and where it is headed for.

For the sake of this study, the research corpus was obtained in the Science Citation Index and in the Social Science Citation Index. 1,725 articles were retrieved, which have been published in journals of various thematic

ELIA Mon. I, pp. 235-370 DOI: http://dx.doi.org/10.12795/elia.mon.2019.i1.13 
areas. The results show a sharp increase in scientific production. 37 annual papers have been published on average since 1968 and about 128 annual papers if only the last decade is taken into consideration. Additionally, a high degree of multidisciplinarity and participation has been noticed in different areas such as education, linguistics or humanities.

Key words: Bilingual education, bilingualism, CLIL, research, bibliometric study

Elobjetivo de este artículo es analizar a través de indicadores bibliométricos la literatura cientifica relacionada con la educación bilingüe publicada entre 1968 y septiembre de 2018. La educación bilingüe moldea los sistemas educativos actuales en todo el mundo. El bilingüismo es, por lo tanto, un fenómeno latente en la sociedad actual y el número de prácticas educativas que incluyen al menos dos lenguas en el proceso de aprendizaje va en aumento. De ahi la necesidad de llevar a cabo un estudio con el objeto de conocer donde nos encontramos en cuanto a investigación se refiere y hacia dónde esta se dirige.

En cuanto al estudio que aqui se presenta, el corpus de investigación se obtuvo en el Science Citation Index y en el Social Science Citation Index. Se obtuvieron 1.725 artículos, los cuales han sido publicados en revistas de varios ámbitos temáticos. Los resultados muestran un pronunciado aumento en la producción cientifica. Se ha publicado una media de 37 artículos anuales desde 1968 y alrededor de 128 en la última década. Además, los resultados dan cuenta de un alto grado de multiciplinariedad y participación en áreas distintas como la educación, la lingüística y las humanidades.

Palabras clave: Educación bilingüe, bilingüismo, AICLE, investigación, estudio bibliométrico

\section{Introduction}

The emergence of new technologies and, as a result, the unstoppable process of globalization is making it possible for societies to tear down barriers and understand the world from a joint perspective. As Angelelli (2016, p. 34) puts it, "we have moved from the ideology of one language

ELIA Mon. I, pp. 235-370 DOI: http://dx.doi.org/10.12795/elia.mon.2019.i1.13 
one nation to a concept of bi/multilingualism as representing the diversity of the world in which we live today". But this new perspective would not be possible if we did not share common linguistic codes through which we could communicate. This new reality calls for new education systems that have foreign languages at their core. Specialization in one area of expertise is not sufficient if access to the globalized job market is to be guaranteed. It has to be complemented with a sound knowledge of not only the students' mother tongue, but also additional languages. Consequently, bilingualism is an increasing phenomenon in current educational systems and research into the effects of such practice has been one of main areas of interest at national and international level in educational matter.

Such has been the extent and impact of bilingualism that Grosjean (2010) estimates that more than half the world's population is bilingual. The ability to speak other languages apart from the mother tongue is thus a powerful tool and a must in our ever-increasing globalized world. Bilingualism does not only broaden our horizons and grant us access to a greater and larger labor market (European Commission, 2012), but it has also proven to have positive cognitive benefits on the brain such as a greater bilingual language and reading mastery when simultaneous exposure to two languages takes place at an early age (Petitto, 2009; Bialystok et al. 2007), a delay on the onset of dementia (Alladi et al. 2013) or higher gray matter volume in the inferior parietal cortex (Mecheli et al. 2004).

As a matter of fact, empirical findings highlight that the effects of bilingualism on cognition lead to enhanced executive control in bilingual speakers (Christoffels et al. 2013; Bialystok et al. 2004). Positive effects have been found in infancy (Agnes \& Mehler, 2009; Kovács, 2009), toddlerhood (Poulin-Dubois et al. 2011; Bialystok \& Senman, 2004), continuing through young (Siegal et al. 2009; Carlson \& Meltzoff, 2008) and middle childhood (Bialystok, 2011), young adulthood (Costa et al. 2008) and older age (Bialystok et al. 2004). The bulk of investigations published serves to explain that the interest in bilingual education has grown exponentially in the last decades, justifying thus the need to carry out studies with a view to ascertaining where we stand in terms of research. On this basis, the aim of the study is to conduct a bibliometric analysis that lets scholars be cognizant of the current state of research into bilingual education and anticipate future research trends.

ELIA Mon. I, pp. 235-370 DOI: http://dx.doi.org/10.12795/elia.mon.2019.i1.13 


\section{Literature Review: Bilingual Education Practices}

As Baker and Wright (2017, p. 197) put it, "bilingual education is a simplistic label for a complex phenomenon". The term bilingual education is commonly used to refer to the education of students who are already speakers in two languages and whose efforts are geared toward the acquisition of academic content. However, foreign language teaching is oftentimes regarded as a form of bilingual education, even though the learning of the language is prized over the acquisition of content. Notwithstanding this, a distinction must be made between education using and promoting two languages and monolingual education in a second language. Whereas the goal in foreign language or second language education is to achieve a high competence in an additional language, the aim of bilingual education is to educate meaningfully and bilingually and help the students to function across cultures. Bilingual education has thus taken different shapes and, consequently, it can be considered a hazy concept (Halbach, 2008) which seeks to define a form of education in which languages constitute a means to achieve a further goal.

Bilingual education calls for a change in the way that teachers conduct their classes. Pavón and Rubio (2010) have referred to this new educational perspective as a methodological revolution which challenges different aspects surrounding the curriculum, e.g. the role of both teachers and students, evaluation and assessment principles, materials development, etc. This type of education promotes the understanding and assimilation of new content through heuristic activities in which students take center stage. All efforts will come to nothing if the way of teaching is not adapted to the principles that govern this form of education, especially when the curricular content is taught through the means of a foreign language that the students do not master. Therefore, there is an impending need to re-evaluate old methods and seek new solutions to the challenges posed by bilingualism in mainstream education.

Bilingual education has drawn a great deal of attention to it worldwide. Anglophone Canadian parents fought hard in the 1970s in order for their children to receive tuition in French through immersion programs and have the same opportunities as their French counterparts (Cummins, 1979; Wesche, 2002). As a result of the great benefits that immersion programs have produced in the Canadian context (Turnbull et

ELIA Mon. I, pp. 235-370 DOI: http://dx.doi.org/10.12795/elia.mon.2019.i1.13 
al. 2003; Turnbull et al. 2001; Halsall, 1998; Lapkin et al. 1990; Genesee, 1987; Holobow et al. 1987; Genesee et al. 1986; Swain \& Lapkin, 1981), these programs have set a precedent in the bilingual education arena and have laid the ground for many other bilingual and plurilingual programs subsequently developed on a global scale.

On the other hand, despite the complexities derived from political, sociological, linguistic or identity issues, among others (Salomone, 2010), the road toward bilingual education in the United States has been a bumpy one due to the English-only language ideology that characterized American education at the beginning of the $20^{\text {th }}$ century so that immigrant students could be "Americanized" (Flores \& García, 2017; Bybee, Henderson \& Hinojosa, 2014). However, the ever-increasing great influx of immigrants arriving at their schools has led to the blossoming of different bilingual programs in the American society such as submersion, heritage or transitional programs, among others (Baker \& Wright, 2017; García, 2009), especially for students whose native or home language is not English and who are learning English as a second language (Gándara \& Escamilla, 2017).

Nevertheless, over the past two decades, new types of bilingual educational programs referred to as dual language education or two-way immersion have emerged (Bybee, Henderson \& Hinojosa, 2014) with a view to granting both immigrant and American students access to this form of education. Based on Canadian French immersion programs (Flores \& García, 2017), these programs are geared toward developing not only bilingualism, but also biliteracy and cross-cultural competence (Gándara \& Escamilla, 2017). The great number of foreign-born individuals in the United States and the academic, linguistic and cognitive benefits that these programs offer (García, 2018; Spies et al. 2018; Borrow \& MarkmanPithers, 2016; Umansky \& Reardon, 2014; Verde-Peleato, 2011; Goldenberg, 2008; Barnett et al. 2007; Genesee et al. 2006; LindholmLeary, 2005; Howard, Christian \& Genesee, 2004; Thomas \& Collier, 2002, 2000; Bialystock, 2001; Alanis, 2000) have prompted the creation of bilingual schools all over the country, especially Spanish/English programs in states with a higher number of immigrant students. Content-Based Instruction is another common approach used in the United States. Instead of drawing attention to the foreign language (English) per se, the students access new academic content through the means of the foreign language

ELIA Mon. I, pp. 235-370 DOI: http://dx.doi.org/10.12795/elia.mon.2019.i1.13 
(Stryker \& Leaver, 1997; Snow, 1998). This is thought to be a more natural and effective way of developing competency in English.

In Europe, the EU policy of 'mother tongue plus two other languages for all' agreed in 2002 (European Commission, 2004) has also propelled a great deal of bilingual and plurilingual programs all around the continent following an approach globally known as CLIL (Content and Language Integrated Learning). CLIL is an umbrella term used to refer to "any dualfocused educational context in which an additional language, thus not usually the first language of the learners involved, is used as a medium in the teaching and learning of non-language content" (Marsh, 2002, p. 15). This European linguistic policy is set to tear down barriers in the euro area and help strengthen bonds and mutual understanding among its member states. Despite there being different ways of approaching CLIL (Coyle, Hood \& Marsh, 2010), all programs have as a main priority to extend the students' time of exposure to the L2 so that they can improve their language skills.

Along with the United States and Canada, Europe is one of the most active continents when it comes to research. Since the 1990s, conspicuous strides have been taken in order to define current practices and help improve the quality of bilingual education. Numerous studies have been published on teachers, students and parents' views on bilingual education (Pérez Cañado, 2017; Pena \& Porto, 2008), learning and acquisition of vocabulary and lexicon (Jiménez Catalán \& Agustín, 2017; Tragant et al. 2016; Sylvén \& Ohlander, 2014; Jiménez, Ruiz de Zarobe \& Cenoz, 2006), students' L2 proficiency (Pérez Cañado, 2018; Merino \& Lasagabaster, 2018; Ackerl, 2007; Mewald, 2007; Serra, 2007; Admiraal et al. 2006) and L1 proficiency (Merisuo-Storm, 2007), students' cognitive development (Jäppinen, 2005), teachers' linguistic and methodological training needs (Pérez Cañado, 2016; Fernández \& Halbach, 2011; Martín del Pozo, 2011; Rubio Mostacero, 2009), students' starting age (Van de Craen et al. 2007; Lorenzo et al. 2009), motivation (Lasagabaster \& López Beloqui, 2015), amongst others.

A perusal of all the main studies published evinces that, despite there having been a lot of research and discussion in the last two decades, the results deriving from empirical data are at variance when it comes to laying the foundations of bilingual education (Broca, 2016). This lack of 
agreement has led the scientific community to conduct unparalleled research with a view to achieving some common ground that help us fully fathom the intricacies of bilingual education. The large number of publications inundating the research arena are proof of this new trend. Therefore, a bibliometric study on bilingualism seems to be much-needed and welcome, as it can help understand how research into bilingual education is developing and where it is headed for.

\section{The Bibliometric Study: Defining the Basics}

Bibliometrics is a discipline that deals mainly with the application of statistical techniques to the study of scientific publications and the bibliographic elements that this area of study contains in order to obtain information about the behavior followed by science and scientists (Zulueta, 2002). Therefore, as Van Doorslaer (2016, p. 168) puts it, "bibliometric methods offer tools for measuring, quantifying, quantitatively analyzing, and exploring academic literature and its impact".

Bibliometrics has become a standard tool of science policy and research management in the last decades. All significant compilations of science indicators heavily rely on publication and citation statistics and other more sophisticated bibliometric techniques. Furthermore, bibliometric or scientific studies are currently an essential tool for the analysis and evaluation of research carried out worldwide (Bordons, 2004). Bibliometrics has become a generic term for a whole range of specific measurements and indicators.

\subsection{Bibliometric Indicators}

Bibliometric indicators are used, on the one hand, to analyze the size, growth and distribution of scientific literature (books, journals, patents, etc.) and, on the other hand, to analyze the processes of generation, propagation and use of the scientific literature (Sancho, 1990). The main and best-known bibliometric indicators can be grouped into two different categories: (a) quantitative indicators of scientific activity, which offer the number of publications and is one of the most useful indicators; and (b) impact indicators, based on the number of citations obtained by the research

ELIA Mon. I, pp. 235-370 DOI: http://dx.doi.org/10.12795/elia.mon.2019.i1.13 
unit (organization, group, investigator, country, etc.) and characterizing the impact of this production based on the recognition granted by other researchers (Bordons \& Zulueta, 1999).

\subsection{Quantitative Indicators of Science Activity}

Quantitative indicators are obtained from the count of the bibliographic elements contained in the records, their description and the information provided. These indicators include:

- Number of papers per country, institution, research group, author or discipline within a given period.

- Coefficient of productivity of the author.

- Temporal evolution of scientific production.

- Analysis of the thematic research areas.

\subsection{Impact Indicators}

Impact indicators measure the effect of a publication on subsequent studies and are calculated from the analysis of citations received in journals included in the Science Citation Index and Scopus (Glänzel \& Moed, 2002). The most common indicators are:

- Impact factor.

- Indicators based on citations: total number of citations, average citations by author, institutions and countries and most cited articles.

\subsection{Collaboration Indicators}

Social Network Analysis (SNA) studies the relationship between a number of elements (individuals, groups, organizations, countries, etc.) (Molina,

ELIA Mon. I, pp. 235-370ＤOI: http://dx.doi.org/10.12795/elia.mon.2019.i1.13 
2001). This type of analysis allows for quantifying how many members make up a network, what is the intensity of the relationships between its members and who are the most relevant of them (González-Alcaide et al. 2008). This section analyzes the following items:

- Index of collaboration or co-author index.

- Collaboration coefficient.

- Index of signatures per work.

- Index of authors per work.

- Total number of signatures in the works.

- Total number of different authors with whom a researcher has collaborated.

- Order of the author's signature in the works.

- Number of works as sole signer and percentage value over total scientific output.

- Index of institutional collaboration.

- Analysis of the personal network, that is, co-authorship and collaboration networks based on the quantification of signatures in the works.

- Analysis of the institutions network.

\subsection{Methodology and Materials}

For the sake of this research, papers published in the Science Citation Index Expanded (SCIE) and Social Science Citation Index (SSCI) have been taken into consideration. Both indexes were accessed from the Web of Science (WOS) database. The bibliographic search was carried out during the month of September 2018 through a search profile implemented

ELIA Mon. I, pp. 235-370ＤOI: http://dx.doi.org/10.12795/elia.mon.2019.i1.13 
in four command search equations in order to retrieve papers on bilingual education until the $20^{\text {th }}$ of September 2018 , discarding other documentary typologies such as proceeding papers, abstracts and reviews.

The search terms linked to bilingual education used in this investigation were the following: 'bilingual educat*'; 'multilingual educat*'; 'immersion education'; 'plurilingual educat*'; 'CLIL'; 'Content and Language Integrated Learning'; 'Content-based instruction'; 'Communicative Language Teaching'. The asterisk determines the word lexemes and includes all the terms derived from it, such as plurals (educations, educators) or others (educative). Despite English as a Medium of Instruction (EMI) being a very habitual term in the literature, it has been discarded for being more commonly linked to tertiary education. Due to space limitations, only articles written in English were accessed, discarding, thus, articles written in additional languages.

The search strategy was implemented in two equations or search lines, which were combined into a final search line so as to discard possible duplicates. Likewise, the scientific content fields of the bibliographic records that were included in the topic query field were: title, author keywords, keywords plus and abstract.

Based on the retrieved bibliographic records, a relational database was created with information related to authors, articles (title, abstract and keywords), year of publication, institutional affiliation, countries and number of citations received. In addition, in order to grant reliability to the study, a screening process was carried out to discard papers that do not match the search equation. Additionally, an analysis of all the abstracts was performed in order to guarantee that all papers not belonging to bilingual education research were excluded, insuring thus the reliability of the evidence reviewed. Consequently, of the 1,840 articles retrieved, 115 were deleted.

One of the limitations in the Web of Science is the lack of uniformity in the name of authors, institutions and countries. As a result, it is essential to normalize the information before carrying out the bibliometric study. This lack of uniformity is usually due to the authors themselves not always signing in the same form and errors in the processing of information. Normalization thus helps unify the different variants of the names of the 
same author or institution under a common denomination. For the normalization of the authors, the criterion that was followed before two or further variants of the same name and surname consisted in choosing the one that yielded more information. In case of doubt, the coincidence was verified in the work places of the variants available.

\section{Results of the Study}

During the period of analysis, 1,725 published papers were collected. The first article registered in the WOS dates back to 1968. As shown in Figure 1 , the number of published papers has grown exponentially since the 20042008 period, when 116 articles were published. The greatest growth, however, has occurred in the last five-year period (2014-2018), when $44.23 \%$ of the articles have been published. Also, the highest peak in the number of citations can be found between 2009-2013, which runs parallel to the number of papers being published regarding bilingual education and, therefore, shows an increasing growth in scientific research.

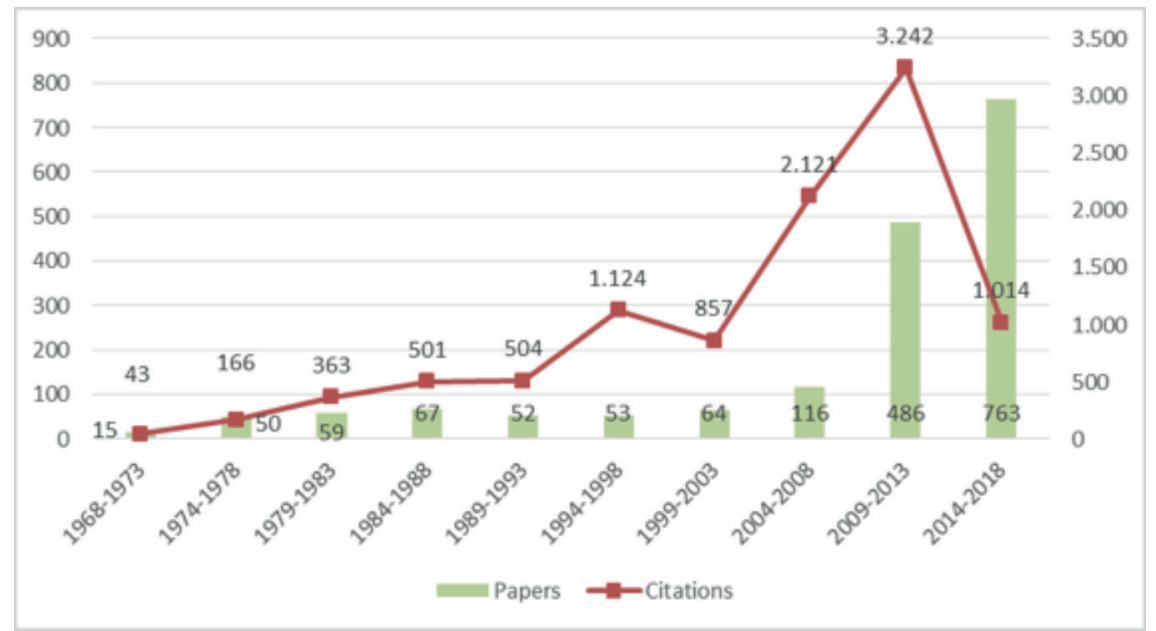

Figure 1. Temporal evolution of published papers

The papers were published in 940 different journals. The journals publishing 10 or more papers are shown in Table 1, along with the country,

ELIA Mon. I, pp. 235-370 DOI: http://dx.doi.org/10.12795/elia.mon.2019.i1.13 
the number of published papers, the citation index and the 5-year impact factor. As can be observed, with the exception of 4 journals, all the rest are British and American journals. This could be due to the fact that the search terms used in this paper have been in English, discarding thus terms in other languages.

\begin{tabular}{|c|c|c|c|c|c|}
\hline Journals & Country & $\begin{array}{c}\text { No. of } \\
\text { papers }\end{array}$ & Citations & $\begin{array}{c}\text { Citations } \\
\text { per paper }\end{array}$ & $\begin{array}{c}\text { 5-Year } \\
\text { Impact } \\
\text { Factor }\end{array}$ \\
\hline $\begin{array}{c}\text { International Journal of } \\
\text { Bilingual Education and } \\
\text { Bilingualism }\end{array}$ & England & 396 & 1,525 & 3.85 & 2.128 \\
\hline Language and Education & England & 55 & 172 & 3.13 & 1.487 \\
\hline $\begin{array}{c}\text { Journal of Multilingual } \\
\text { and Multicultural } \\
\text { Development }\end{array}$ & England & 45 & 126 & 2.80 & 1.273 \\
\hline Porta Linguarum & Spain & 43 & 49 & 1.14 & 0.559 \\
\hline $\begin{array}{c}\text { Foreign Language } \\
\text { Annals }\end{array}$ & United States & 43 & 285 & 6.63 & 1.286 \\
\hline $\begin{array}{c}\text { Language Culture and } \\
\text { Curriculum }\end{array}$ & England & 42 & 110 & 2.62 & 1.316 \\
\hline TESOL Quarterly & United States & 40 & 1,163 & 29.08 & 2.828 \\
\hline $\begin{array}{c}\text { Canadian Modern } \\
\text { Language Review-Revue } \\
\text { Canadienne Des Langues }\end{array}$ & Canada & 31 & 201 & 6.48 & 1.000 \\
\hline Vivantes & & 28 & 415 & 14.82 & 2.578 \\
\hline $\begin{array}{c}\text { Modern Language } \\
\text { Journal }\end{array}$ & United States & 28 & 182 & 7.28 & 1.826 \\
\hline System & England & 25 & 273 & 15.17 & 1.648 \\
\hline Language Policy & Netherlands & 21 & 115 & 5.48 & 1.554 \\
\hline Educational Policy & United States & 18 & & & \\
\hline
\end{tabular}

ELIA Mon. I, pp. 235-370ＤOI: http://dx.doi.org/10.12795/elia.mon.2019.i1.13 


\begin{tabular}{|c|c|c|c|c|c|}
\hline Journals & Country & $\begin{array}{l}\text { No. of } \\
\text { papers }\end{array}$ & Citations & $\begin{array}{l}\text { Citations } \\
\text { per paper }\end{array}$ & $\begin{array}{l}\text { 5-Year } \\
\text { Impact } \\
\text { Factor }\end{array}$ \\
\hline $\begin{array}{c}\text { International Journal of } \\
\text { Educational } \\
\text { Development }\end{array}$ & England & 17 & 141 & 8.29 & 1.677 \\
\hline $\begin{array}{l}\text { Teaching and Teacher } \\
\text { Education }\end{array}$ & England & 15 & 103 & 6.87 & 3.335 \\
\hline $\begin{array}{l}\text { Journal of Language } \\
\text { Identity and Education }\end{array}$ & United States & 14 & 12 & 0.86 & 0.721 \\
\hline Applied Linguistics & England & 14 & 378 & 27.00 & 3.899 \\
\hline Language Teaching & England & 13 & 49 & 3.77 & 3.215 \\
\hline $\begin{array}{l}\text { Anthropology \& } \\
\text { Education Quarterly }\end{array}$ & United States & 13 & 76 & 5.85 & 1.183 \\
\hline $\begin{array}{c}\text { International Journal of } \\
\text { the Sociology of } \\
\text { Language }\end{array}$ & & 12 & 2 & 0.17 & \\
\hline Hispania - AATSP & United States & 12 & 10 & 0.83 & 0.289 \\
\hline Educational Leadership & United States & 12 & 40 & 3.33 & 0.465 \\
\hline $\begin{array}{l}\text { Linguistics and } \\
\text { Education }\end{array}$ & Netherlands & 12 & 20 & 1.67 & \\
\hline $\begin{array}{l}\text { Hispanic Journal of } \\
\text { Behavioral Sciences }\end{array}$ & United States & 11 & 88 & 8.00 & 1.144 \\
\hline Comparative Education & England & 11 & 71 & 6.45 & 2.034 \\
\hline
\end{tabular}

Table 1. Journals with most published papers

The institutions with 10 or more published papers, along with the country, the total number of citations that these papers have received and the average number of citations received per published article, are presented in Table 2. In line with the journals publishing more papers, English-speaking universities are among the most productive, which can be attributed once again to the fact that the key words utilized in our

ELIA Mon. I, pp. 235-370 DOI: http://dx.doi.org/10.12795/elia.mon.2019.i1.13 
search have all been in English. Nevertheless, it is worthwhile noting that the University of the Basque Country in Spain appears first in the ranking. Three other Spanish universities are included in the list, two of them belonging to bilingual regions (the Basque Country and Catalonia). The United States is the country with more universities publishing research papers regarding bilingual education $(n=11)$. Additionally, the number of publications is not proportional to the citations received and, as a result, the average number of citations per published article can vary greatly.

\begin{tabular}{|c|c|c|c|c|}
\hline Institution & Country & $\begin{array}{c}\text { No. of } \\
\text { papers }\end{array}$ & $\begin{array}{c}\text { No. of } \\
\text { citations }\end{array}$ & $\begin{array}{c}\text { Average of } \\
\text { citations } \\
\text { per work }\end{array}$ \\
\hline Universidad del País Vasco & Spain & 41 & 166 & 4.05 \\
\hline Arizona State University & United States & 25 & 338 & 13.52 \\
\hline $\begin{array}{c}\text { University of Texas at } \\
\text { Austin }\end{array}$ & United States & 23 & 171 & 7.43 \\
\hline University of Hong Kong & China & 22 & 69 & 3.14 \\
\hline University of Pennsylvania & United States & 22 & 364 & 16.55 \\
\hline McGill University & Canada & 18 & 267 & 14.83 \\
\hline $\begin{array}{c}\text { Universitat Autònoma de } \\
\text { Barcelona }\end{array}$ & Spain & 18 & 52 & 2.89 \\
\hline Texas A\&M University & United States & 18 & 54 & 3.00 \\
\hline $\begin{array}{c}\text { University of Texas at San } \\
\text { Antonio }\end{array}$ & United States & 18 & 76 & 4.22 \\
\hline $\begin{array}{c}\text { University of Colorado } \\
\text { Boulder }\end{array}$ & United States & 15 & 89 & 5.93 \\
\hline $\begin{array}{c}\text { Nanyang Technological } \\
\text { University }\end{array}$ & Singapore & 15 & 160 & 10.67 \\
\hline $\begin{array}{c}\text { Bangor University } \\
\text { Kingdom }\end{array}$ & 15 & 77 & 5.13 \\
\hline
\end{tabular}

ELIA Mon. I, pp. 235-370 DOI: http://dx.doi.org/10.12795/elia.mon.2019.i1.13 


\begin{tabular}{|c|c|c|c|c|}
\hline Institution & Country & $\begin{array}{l}\text { No. of } \\
\text { papers }\end{array}$ & $\begin{array}{l}\text { No. of } \\
\text { citations }\end{array}$ & $\begin{array}{l}\text { Average of } \\
\text { citations } \\
\text { per work }\end{array}$ \\
\hline University of Toronto & Canada & 15 & 126 & 8.40 \\
\hline Hunter College & United States & 14 & 83 & 5.93 \\
\hline $\begin{array}{l}\text { Pennsylvania State } \\
\text { University }\end{array}$ & United States & 13 & 129 & 9.92 \\
\hline Washington State University & United States & 13 & 138 & 10.62 \\
\hline Oranim Academic College & Israel & 12 & 23 & 1.92 \\
\hline University of Edinburgh & $\begin{array}{l}\text { United } \\
\text { Kingdom }\end{array}$ & 12 & 52 & 4.33 \\
\hline Universitat de Lleida & Spain & 12 & 34 & 2.83 \\
\hline $\begin{array}{l}\text { Universidad Autónoma de } \\
\text { Madrid }\end{array}$ & Spain & 12 & 51 & 4.25 \\
\hline University of Jyväskylä & Finland & 12 & 17 & 1.42 \\
\hline University of Haifa & Israel & 12 & 66 & 5.50 \\
\hline $\begin{array}{l}\text { Radboud University } \\
\text { Nijmegen }\end{array}$ & $\begin{array}{l}\text { The } \\
\text { Netherlands }\end{array}$ & 11 & 146 & 13.27 \\
\hline CUNY Graduate Center & United States & 11 & 44 & 4.00 \\
\hline York University & Canada & 11 & 108 & 9.82 \\
\hline Michigan State University & United States & 11 & 88 & 8.00 \\
\hline
\end{tabular}

Table 2. Institutions with 10 or more published papers

Regarding the distribution of papers by country (Table 3 ), the country with the highest number of publications is the United States $(n=534)$, followed by Spain $(n=229)$, the United Kingdom $(n=143)$ and Canada $(n=99)$. For citations, the United States is in the top position $(n=4.231)$, followed by Canada $(n=815)$, Spain $(n=632)$ and the United Kingdom $(\mathrm{n}=595)$. The average of citations per paper is higher for Austria $(n=9.59)$, Canada $(n=8.23)$ and Singapore $(n=8.05)$.

ELIA Mon. I, pp. 235-370 DOI: http://dx.doi.org/10.12795/elia.mon.2019.i1.13 


\begin{tabular}{|c|c|c|c|}
\hline Country & Papers & Citations & $\begin{array}{c}\text { Average of citations } \\
\text { per work }\end{array}$ \\
\hline United States & 534 & 4,231 & 7.92 \\
\hline Spain & 229 & 632 & 2.76 \\
\hline United Kingdom & 143 & 595 & 4.16 \\
\hline Canada & 99 & 815 & 8.23 \\
\hline China & 79 & 432 & 5.47 \\
\hline Australia & 69 & 374 & 5.42 \\
\hline Germany & 38 & 169 & 4.45 \\
\hline Sweden & 36 & 161 & 4.47 \\
\hline South Africa & 34 & 105 & 3.09 \\
\hline The Netherlands & 33 & 205 & 6.21 \\
\hline Israel & 27 & 107 & 3.96 \\
\hline Finland & 24 & 65 & 2.71 \\
\hline Japan & 22 & 82 & 3.73 \\
\hline Singapore & 20 & 161 & 8.05 \\
\hline New Zealand & 18 & 62 & 3.44 \\
\hline Belgium & 18 & 68 & 3.78 \\
\hline South Korea & 18 & 53 & 2.94 \\
\hline Ireland & 18 & 71 & 3.94 \\
\hline Austria & 17 & 163 & 9.59 \\
\hline Taiwan & 16 & 44 & 2.75 \\
\hline Italy & 16 & 34 & 2.13 \\
\hline Poland & 16 & 40 & 2.50 \\
\hline France & 15 & 40 & 2.67 \\
\hline
\end{tabular}

ELIA Mon. I, pp. 235-370 DOI: http://dx.doi.org/10.12795/elia.mon.2019.i1.13 


\begin{tabular}{l|l|l|l} 
Malta & 11 & 19 & 1.73 \\
\hline
\end{tabular}

Table 3. Countries with more publications

The most common key words found in the papers that make up our corpus of analysis and the total percentages are presented in Table 4. The key phrase bilingual education appears in 425 papers, followed by language with 287 and Content and Language Integrated Learning (CLIL) with 265 . The following is the general term education $(\mathrm{n}=218)$ and the next one is English $(\mathrm{n}=152)$. The other terms which follow with 100 or more correspondences are: bilingualism $(\mathrm{n}=150)$, students $(\mathrm{n}=141)$, children $(\mathrm{n}=127)$ and second language (102). The use of terms such as language or children may be striking; however, the close relationship between second language practice and early stages of education may explain the use of the terms in some of the articles analyzed. As regards languages, both English $(\mathrm{n}=152)$ and Spanish $(\mathrm{n}=58)$ appear to be the most recurring words.

\begin{tabular}{|c|c|c|}
\hline Key words & Papers & \% total \\
\hline Bilingual education & 425 & $3.44 \%$ \\
\hline Language & 287 & $2.32 \%$ \\
\hline $\begin{array}{c}\text { Content and language integrated learning } \\
\text { (CLIL) }\end{array}$ & 265 & $2.14 \%$ \\
\hline Education & 218 & $1.76 \%$ \\
\hline English & 152 & $1.23 \%$ \\
\hline Bilingualism & 150 & $1.21 \%$ \\
\hline Students & 141 & $1.14 \%$ \\
\hline Children & 127 & $1.03 \%$ \\
\hline Second language & 102 & $0.83 \%$ \\
\hline Language policy & 96 & $0.78 \%$ \\
\hline Classroom & 94 & $0.76 \%$ \\
\hline School & 89 & $0.72 \%$ \\
\hline
\end{tabular}

ELIA Mon. I, pp. 235-370 DOI: http://dx.doi.org/10.12795/elia.mon.2019.i1.13 


\begin{tabular}{|c|c|c|}
\hline Acquisition & 89 & $0.72 \%$ \\
\hline Instruction & 79 & $0.64 \%$ \\
\hline Literacy & 79 & $0.64 \%$ \\
\hline Immersion & 74 & $0.60 \%$ \\
\hline Learners & 73 & $0.59 \%$ \\
\hline Policy & 67 & $0.54 \%$ \\
\hline Multilingualism & 67 & $0.54 \%$ \\
\hline Teachers & 66 & $0.53 \%$ \\
\hline Identity & 60 & $0.49 \%$ \\
\hline Spanish & 58 & $0.47 \%$ \\
\hline English Language Learner (ELL) & 58 & $0.47 \%$ \\
\hline Bilingual & 57 & $0.46 \%$ \\
\hline Content-based instruction (CBI) & 56 & $0.45 \%$ \\
\hline Second Language Acquisition (SLA) & 54 & $0.44 \%$ \\
\hline Foreign Language (FL) & 53 & $0.43 \%$ \\
\hline Achievement & 51 & $0.41 \%$ \\
\hline
\end{tabular}

Table 4. Key word analysis

Table 5 shows research areas with more than 10 articles published, the total number of citations received and the average number of citations per published article. As shown, bilingual education seems to be present in various areas of expertise, which shows that bilingual education has gained ground in diverse disciplines other than Education, Linguistics and Psychology.

Figure 2 shows the network of co-words in which the diameter of the spheres is proportional to the frequency of keywords in the set of articles. The thickness of the lines connecting the key words is proportional to the number of times that two words coincide in the set of articles. The 


\begin{tabular}{|c|c|c|c|}
\hline Research area & $\begin{array}{c}\text { No. of } \\
\text { papers }\end{array}$ & $\begin{array}{c}\text { No. of } \\
\text { citations }\end{array}$ & $\begin{array}{c}\text { Average of } \\
\text { citations per } \\
\text { work }\end{array}$ \\
\hline $\begin{array}{c}\text { Education \& Educational } \\
\text { Research }\end{array}$ & 1,084 & 6,762 & 6.24 \\
\hline Linguistics & 1,005 & 5,872 & 5.84 \\
\hline Psychology. Educational & 48 & 343 & 7.15 \\
\hline Education. Special & 23 & 242 & 10.52 \\
\hline Psychology. Experimental & 23 & 437 & 19.00 \\
\hline Rehabilitation & 22 & 250 & 11.36 \\
\hline Anthropology & 21 & 107 & 5.10 \\
\hline $\begin{array}{c}\text { Social Sciences. } \\
\text { Interdisciplinary }\end{array}$ & 21 & 49 & 2.33 \\
\hline Political Science & 19 & 132 & 6.95 \\
\hline Psychology. Multidisciplinary & 18 & 120 & 6.67 \\
\hline Psychology. Developmental & 17 & 165 & 9.71 \\
\hline Sociology & 14 & 60 & 4.29 \\
\hline Economics & 12 & 44 & 3.67 \\
\hline
\end{tabular}

Table 5. Research areas analysis

threshold applied is more than 10 co-occurrences in common. The total number of key words drawn in the network was 46.

Not surprisingly, at the center of the keyword network can be found the word bilingual education connected with a thick line with language, bilingualism, students, children, education or CLIL. All of these words are at the same time interconnected. The word English can also be considered interrelated with the most repeated words in the articles. The word Spanish is not represented because the threshold of co-occurrences in common was fixed in 10 and Spanish has lower common occurrences. Thus, Spanish becomes the second most used language. Other related terms can also be

ELIA Mon. I, pp. 235-370 DOI: http://dx.doi.org/10.12795/elia.mon.2019.i1.13 


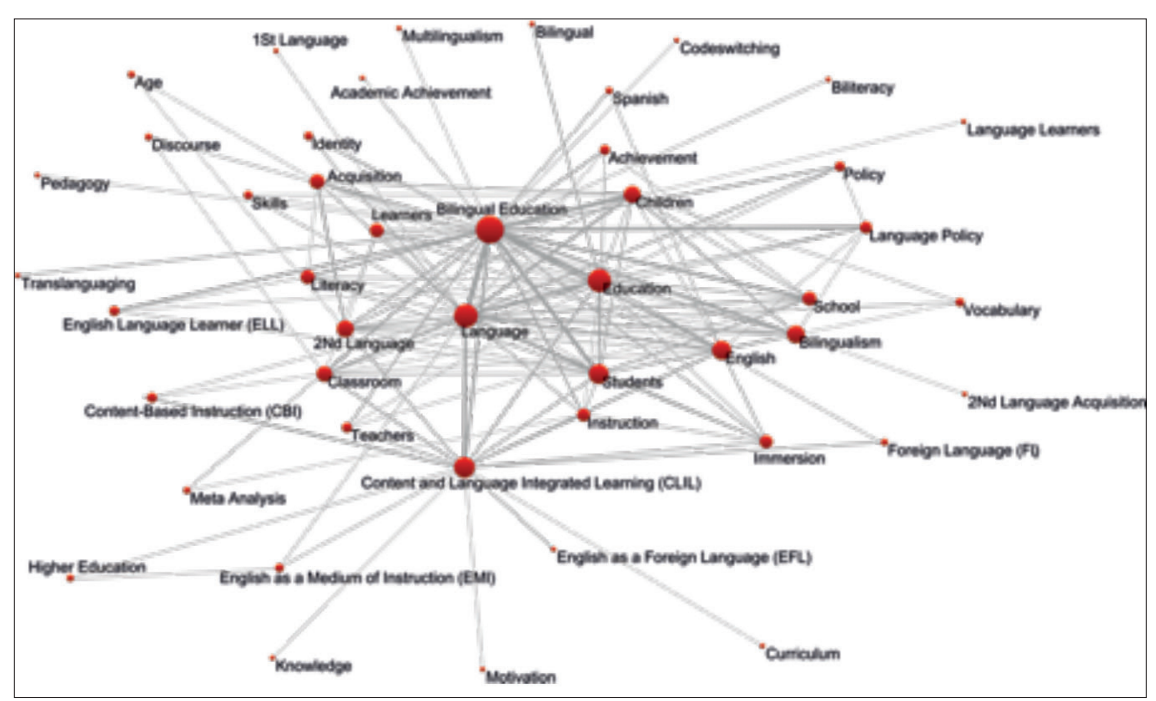

Figure 2. Network of co-words.

found on the periphery such as English as a Foreign Language (EFL), Foreign Language (FL), Content-Based Instruction (CBI), Second Language Acquisition (SLA), English as a Medium of Instruction (EMI), English Language Learner (ELL), multilingualism, code-switching and language policy, among others.

As regards the collaboration index, it has been studied from three different perspectives: collaboration among authors, institutions and countries. First, in terms of collaboration between authors, it can be seen that the average index is approximately two, meaning that most published works are signed by two authors. Then, in relation to collaboration between institutions, we notice an increase over time going from an index of 1.18 institutions per paper at the beginning of the analyzed period to 1.52 at the end of the period. Finally, regarding the collaboration between countries, the relationship between them does not seem very significant since the average of the analyzed period is only 1.15 countries per paper.

Figure 4 shows the network of collaboration between institutions. The size of the spheres is proportional to the total number of collaborations 


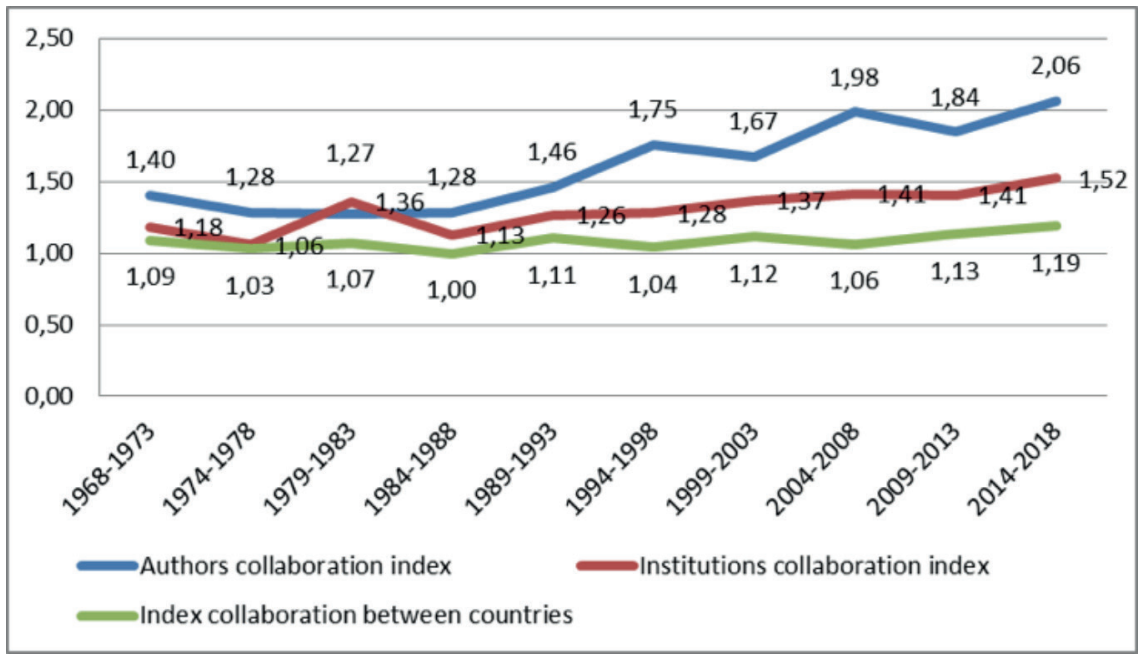

Figure 3. Collaboration index

by each institution. As can be observed, the results point to a weak collaboration index among institutions. In connection with previous data, American universities are the ones establishing a higher rate of cooperation among themselves.

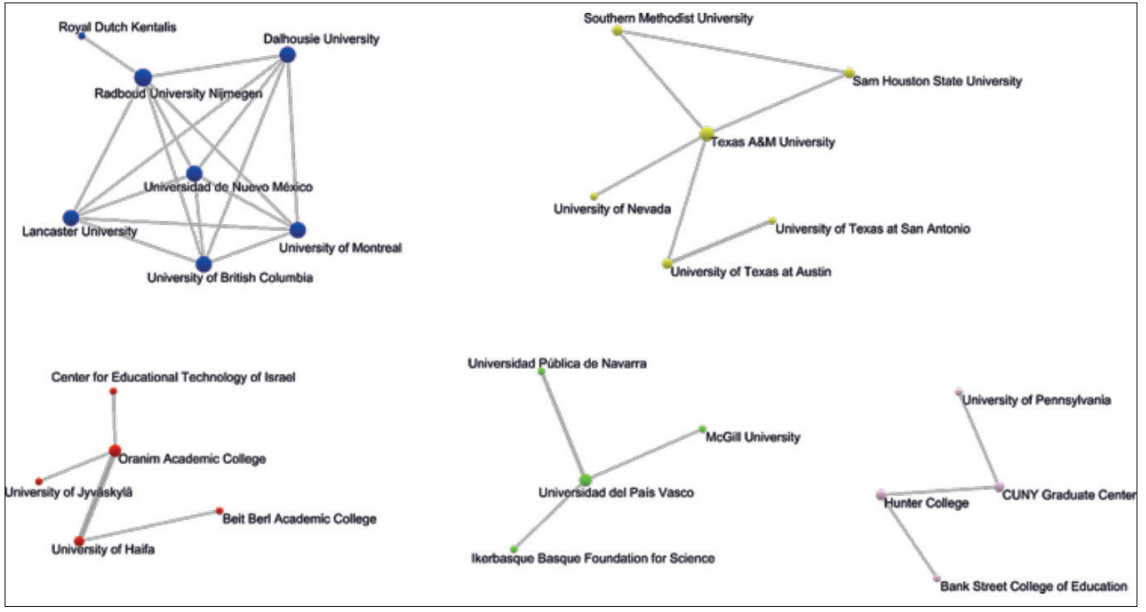

Figure 4. Collaboration between institutions

ELIA Mon. I, pp. 235-370ＤOI: http://dx.doi.org/10.12795/elia.mon.2019.i1.13 


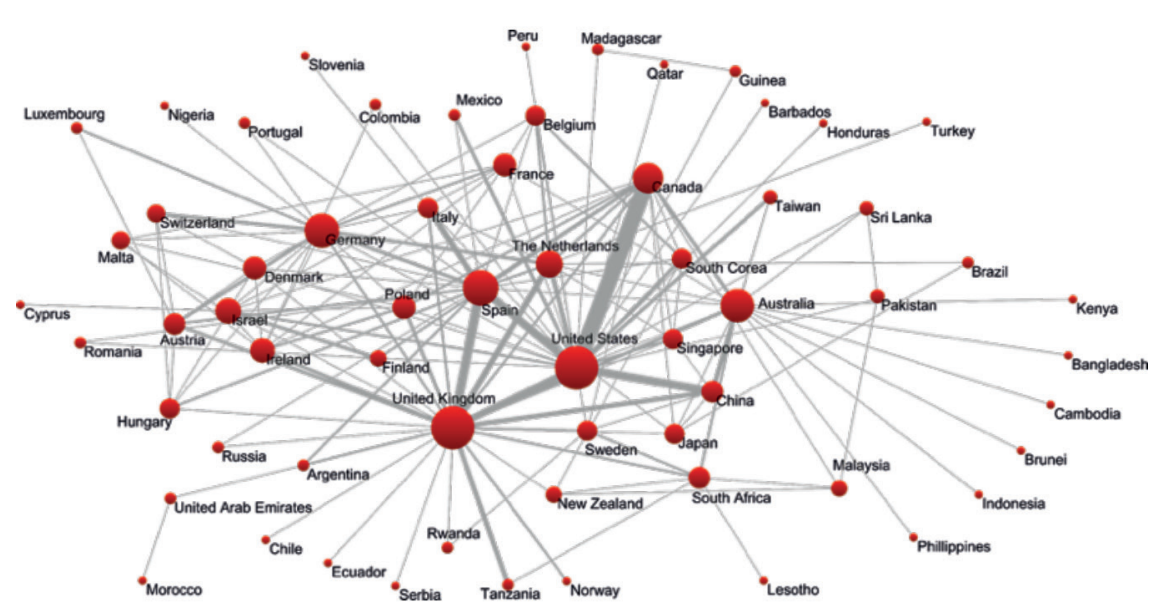

Figure 5. Collaboration between countries

The country collaboration network is presented in Figure 5 and includes 62 countries, highlighting the most intense collaboration between the United States and Canada, with 14 collaborations in common, followed by The United Kingdom and Spain with 8 collaborations. In addition, China and the United States have 7 collaborations, the same as the United States and Spain.

Finally, Table 6 shows the papers that have received 100 or more citations between 1968 and 2018.

\begin{tabular}{|c|c|c|c|}
\hline Authors & Title & Source & $\begin{array}{c}\text { Citations } \\
\text { ISI }\end{array}$ \\
\hline Willig, A.C. & $\begin{array}{c}\text { A meta-analysis of selected } \\
\text { studies on the effectiveness of } \\
\text { bilingual education }\end{array}$ & $\begin{array}{c}\text { Review of } \\
\text { Educational } \\
\text { Research 1985; } \\
55(3): 269-317\end{array}$ & 191 \\
\hline Li, D. & $\begin{array}{c}\text { "It's always more difficult than } \\
\text { you plan and imagine": Teacher's } \\
\text { perceived difficulties in } \\
\text { introducing the communicative } \\
\text { approach in South Korea }\end{array}$ & $\begin{array}{c}\text { TESOL } \\
\text { Quarterly } \\
\text { 1998; 32 (4): } \\
677-703\end{array}$ & 135 \\
\hline
\end{tabular}

ELIA Mon. I, pp. 235-370ＤOI: http://dx.doi.org/10.12795/elia.mon.2019.i1.13 


\begin{tabular}{|c|c|c|c|}
\hline Authors & Title & Source & $\begin{array}{l}\text { Citations } \\
\text { ISI }\end{array}$ \\
\hline $\begin{array}{l}\text { Slavin, R.E.; } \\
\text { Cheung, A. }\end{array}$ & $\begin{array}{l}\text { A synthesis of research on } \\
\text { language of reading instruction for } \\
\text { English language learners }\end{array}$ & $\begin{array}{l}\text { Review of } \\
\text { Educational } \\
\text { Research 2005; } \\
75 \text { (2): } 247-284\end{array}$ & 133 \\
\hline $\begin{array}{l}\text { Ricento, T.K.; } \\
\text { Hornberger, } \\
\text { N.H. }\end{array}$ & $\begin{array}{l}\text { Unpeeling the onion: Language } \\
\text { planning and policy and the ELT } \\
\text { professional }\end{array}$ & $\begin{array}{c}\text { TESOL } \\
\text { Quarterly } \\
1996 ; 30(3): \\
401-427\end{array}$ & 127 \\
\hline Cummins, J. & $\begin{array}{c}\text { The cross-lingual dimensions of } \\
\text { language proficiency: Implications } \\
\text { for bilingual education and the } \\
\text { optimal age issue }\end{array}$ & $\begin{array}{c}\text { TESOL } \\
\text { Quarterly } \\
1980 ; 14(2): \\
175-187 \\
\end{array}$ & 121 \\
\hline $\begin{array}{l}\text { Rolstad, K.; } \\
\text { Mahoney, K.; } \\
\text { Glass, G.V. }\end{array}$ & $\begin{array}{l}\text { The big picture: A meta-analysis } \\
\text { of program effectiveness research } \\
\text { on English language learners }\end{array}$ & $\begin{array}{c}\text { Educational } \\
\text { Policy } \\
2005 ; 19(4): \\
572-594\end{array}$ & 120 \\
\hline $\begin{array}{l}\text { Spelke, ES; } \\
\text { Tsivkin, S. }\end{array}$ & $\begin{array}{l}\text { Language and number: a bilingual } \\
\text { training study }\end{array}$ & $\begin{array}{l}\text { Cognition 2001; } \\
\quad 78 \text { (1): } 45-88\end{array}$ & 119 \\
\hline $\begin{array}{c}\text { Kumaravadivelu, } \\
\text { B. }\end{array}$ & $\begin{array}{l}\text { TESOL methods: Changing } \\
\text { tracks, challenging trends }\end{array}$ & $\begin{array}{c}\text { TESOL } \\
\text { Quarterly } \\
\text { 2006; } 40(1) \text { : } \\
59-81\end{array}$ & 118 \\
\hline Auerbach, E.R. & $\begin{array}{l}\text { Reexamining English only in the } \\
\text { ESL classroom }\end{array}$ & $\begin{array}{c}\text { TESOL } \\
\text { Quarterly 1993; } \\
27 \text { (1): 9-32 } \\
\end{array}$ & 103 \\
\hline $\begin{array}{l}\text { Schleppegrell, } \\
\text { M.J.; Achugar, } \\
\text { M.; Oteiza, T. }\end{array}$ & $\begin{array}{c}\text { The grammar of history: } \\
\text { Enhancing content-based } \\
\text { instruction through a functional } \\
\text { focus on language }\end{array}$ & $\begin{array}{c}\text { TESOL } \\
\text { Quarterly } \\
\text { 2004; } 38(1) \text { : } \\
67-93\end{array}$ & 99 \\
\hline $\begin{array}{c}\text { Bankston, C.L.; } \\
\text { Zhou, M. }\end{array}$ & $\begin{array}{c}\text { Effects of minority-language } \\
\text { literacy on the academic- } \\
\text { achievement of Vietnamese youth } \\
\text { in New-Orleans }\end{array}$ & $\begin{array}{c}\text { Sociology of } \\
\text { Education } \\
1995 ; 68(1) \\
1-17\end{array}$ & 96 \\
\hline
\end{tabular}

ELIA Mon. I, pp. 235-370 DOI: http://dx.doi.org/10.12795/elia.mon.2019.i1.13 


\begin{tabular}{|c|c|c|c|}
\hline Authors & Title & Source & $\begin{array}{c}\text { Citations } \\
\text { ISI }\end{array}$ \\
\hline $\begin{array}{l}\text { Rossell, C.H.; } \\
\text { Baker, K. }\end{array}$ & $\begin{array}{c}\text { The educational effectiveness of } \\
\text { bilingual education }\end{array}$ & $\begin{array}{l}\text { Research in the } \\
\text { Teaching of } \\
\text { English 1996; } \\
30 \text { (1): } 7-74\end{array}$ & 93 \\
\hline Kramsch, C. & $\begin{array}{l}\text { Teaching Foreign Languages in an } \\
\text { Era of Globalization: Introduction }\end{array}$ & $\begin{array}{c}\text { Modern } \\
\text { Language } \\
\text { Journal } \\
\text { 2014; } 98(1) \text { : } \\
\text { 296-311 }\end{array}$ & 90 \\
\hline Valdes, G. & $\begin{array}{l}\text { Dual-language immersion } \\
\text { programs: A cautionary note } \\
\text { concerning the education of } \\
\text { language-minority students }\end{array}$ & $\begin{array}{c}\text { Harvard } \\
\text { Educational } \\
\text { Review } \\
\text { 1997; } 67(3): \\
\text { 391-429 }\end{array}$ & 82 \\
\hline $\begin{array}{l}\text { Dalton-Puffer, } \\
\text { C. }\end{array}$ & $\begin{array}{c}\text { Content-and-Language Integrated } \\
\text { Learning: From Practice to } \\
\text { Principles? }\end{array}$ & $\begin{array}{l}\text { Annual Review } \\
\text { of Applied } \\
\text { Linguistics } \\
\text { 2011: 182-204 }\end{array}$ & 76 \\
\hline $\begin{array}{l}\text { Spada, N.; } \\
\text { Lightbown, } \\
\text { P.M. }\end{array}$ & $\begin{array}{l}\text { Form-focused instruction: Isolated } \\
\text { or integrated? }\end{array}$ & $\begin{array}{c}\text { TESOL } \\
\text { Quarterly } \\
\text { 2008; } 42(2) \text { : } \\
181-208\end{array}$ & 71 \\
\hline Savignon, S.J. & $\begin{array}{l}\text { Communicative language } \\
\text { teaching: State of the art }\end{array}$ & $\begin{array}{c}\text { TESOL } \\
\text { Quarterly } \\
1991 ; 25(2) \text { : } \\
261-277\end{array}$ & 70 \\
\hline Hu, G.W. & $\begin{array}{c}\text { Contextual influences on } \\
\text { instructional practices: A Chinese } \\
\text { case for an ecological approach to } \\
\text { ELT }\end{array}$ & $\begin{array}{c}\text { TESOL } \\
\text { Quarterly } \\
\text { 2005; } 39(4): \\
635-660\end{array}$ & 65 \\
\hline Gorsuch, G.J. & $\begin{array}{l}\text { EFL educational policies and } \\
\text { educational cultures: Influences } \\
\text { on teachers' approval of } \\
\text { communicative activities }\end{array}$ & $\begin{array}{c}\text { TESOL } \\
\text { Quarterly } \\
\text { 2000; } 34(4): \\
675-710\end{array}$ & 64 \\
\hline
\end{tabular}

ELIA Mon. I, pp. 235-370 DOI: http://dx.doi.org/10.12795/elia.mon.2019.i1.13 


\begin{tabular}{|c|c|c|c|}
\hline Authors & Title & Source & $\begin{array}{l}\text { Citations } \\
\text { ISI }\end{array}$ \\
\hline $\begin{array}{l}\text { Gatbonton, E; } \\
\text { Segalowitz, N. }\end{array}$ & $\begin{array}{l}\text { Rethinking communicative } \\
\text { language teaching: A focus on } \\
\text { access to fluency }\end{array}$ & $\begin{array}{c}\text { Canadian } \\
\text { Modern } \\
\text { Language } \\
\text { Review } \\
\text { Revue } \\
\text { Canadienne Des } \\
\text { Langues } \\
\text { Vivantes 2005; } \\
61 \text { (3): } 325-353\end{array}$ & 64 \\
\hline Musumeci, D. & $\begin{array}{c}\text { Teacher-learner negotiation in } \\
\text { content-based instruction: } \\
\text { Communication at cross- } \\
\text { purposes? }\end{array}$ & $\begin{array}{l}\text { Applied } \\
\text { Linguistics } \\
\text { 1996; } 17(3) \text { : } \\
286-325\end{array}$ & 62 \\
\hline $\begin{array}{l}\text { Barnett, W.S.; } \\
\text { Yarosz, D.J.; } \\
\text { Thomas, J.; } \\
\text { Jung, K.; } \\
\text { Blanco, D. }\end{array}$ & $\begin{array}{l}\text { Two-way and monolingual } \\
\text { English immersion in preschool } \\
\text { education: An experimental } \\
\text { comparison }\end{array}$ & $\begin{array}{c}\text { Early } \\
\text { Childhood } \\
\text { Research } \\
\text { Quarterly 2007; } \\
22 \text { (3): 277-293 }\end{array}$ & 62 \\
\hline $\begin{array}{l}\text { Sato, K.; } \\
\text { Kleinsasser, } \\
\text { R.C. }\end{array}$ & $\begin{array}{l}\text { Communicative language teaching } \\
\text { (CLT): Practical understandings }\end{array}$ & $\begin{array}{c}\text { Modern } \\
\text { Language } \\
\text { Journal } \\
\text { 1999; } 83(4) \text { : } \\
494-517\end{array}$ & 62 \\
\hline
\end{tabular}

Table 6. Number of citations per paper

\section{Conclusions}

This study has provided helpful insights into the current state of bilingual education research. Many aspects, including the most productive journals, institutions, countries, subject areas and collaboration rates, have been addressed. On the basis of the research findings, we can conclude that research into bilingual education has grown constantly and exponentially. Most of the papers used in this analysis have been published in the last decade, especially since 2012. This may suggest a steady growth in this field of research in the years to come. This growth seems to be in line with 
the international outlook that has more recently shaped global education. What is more, considering the body of literature analyzed, we can state that the study of foreign languages can be found in a wider range of educational stages, ranging from pre-primary schools to university education. This makes thus bilingual education a common practice involving a greater number of both practitioners and researchers.

Although American universities stand among the most productive in bilingual education research, the institution that has contributed the most to research is the University of the Basque Country in Spain. The papers coming from universities mainly located in the United States are the ones which receive the highest number of citations, and Spain is in the second position surpassing other countries such as the United Kingdom, Canada or Australia. It is thus the only non-English speaking country among the leading countries in terms of scientific production. Spanish is also the language with the greatest presence in keywords after English.

This analysis has also brought to the fore the multidisciplinarity that characterizes this field of research. Although the majority of articles have been published in linguistics and education journals, we can also find articles published in journals linked to disciplines such as psychology, law, anthropology, social sciences, etc. As far as collaboration is concerned, cooperation among institutions seems to have increased over time, but collaboration among countries needs to be strengthened. The network of collaboration would definitely allow countries to benefit from each other by carrying out joint research projects.

Finally, it is necessary to highlight some limitations that this study presents. On the one hand, the databases selected for the research corpus in this study, SCIE and SSCI, have a linguistic and geographical bias in favor of English-language journals, especially those in the United States. Nevertheless, these are the databases most commonly employed in bibliometric studies since they include journals with the greatest international impact and provide data and indicators that other databases do not offer. On the other hand, for an article to receive diverse citations, it needs to be published for a certain period of time. Therefore, it would be interesting to discern between the body of articles that have been published recently and those published some years ago. It is also likely that many articles may not have chosen any of the search terms employed as key 
words, excluding thus other articles that could have played a part in this study. Likewise, this is not an all-inclusive review, as book chapters, anthologies and encyclopedias have not been included. Only articles written in English have been reviewed, therefore articles written in additional languages have not been considered in this study.

We can conclude by saying that this study has allowed us to see where we stand when it comes to research into bilingual education and anticipate some future research needs such as joint collaboration among both institutions and countries through research practices and the inclusion of students with special educational needs, as none of the key words gathered refer to these students. As Okubo $(1997$, p. 8) puts it, "the essence of scientific research is the production of knowledge and that scientific literature is the constituent manifestation of that knowledge". Hence, the necessity to review the published literature with a view to qualifying and quantifying the research available.

\section{Acknowledgments}

This study has been supported by research grants GV/2019/121 from Generalitat Valenciana and FUSPBS-PPC10/2017 from Santander Bank Foundation and San Pablo CEU Foundation.

\section{References}

Ackerl, C. (2007). Lexico-Grammar in the essays of CLIL and non-CLIL students: error analysis of written production. Vienna English Working papers (Views), 16(3), 6-11.

Admiraal, W., Westhoff, G. \& de Bot, K. (2006). Evaluation of bilingual secondary education in the Netherlands: students' language proficiency in English. Educational Research and Evaluation, 12(1), 75-93. https://doi. org/10.1080/13803610500392160

Agnes Kovács, M. \& Jacques, M. (2009). Cognitive gains in 7-month-old bilingual infants. PNAS, 106(16), 6556-6560. https://doi.org/10.1073/ pnas. 0811323106

ELIA Mon. I, pp. 235-370 DOI: http://dx.doi.org/10.12795/elia.mon.2019.i1.13 
Alanis, I. (2000). A Texas Two-way Bilingual Program: Its Effects on Linguistic and Academic Achievement. Bilingual Research Journal, 24(3), 225-248. https://doi.org/10.1080/15235882.2000.10162763

Alladi, S., Bak, T.H., Duggirala, V., Surampudi, B., Shailaja, M., Shukla, A.K., Chaudhuri, J.R. \& Kaul, S. (2013). Bilingualism delays age at onset of dementia, independent of education and immigration status. Neurology, 81(22), 1938-1944. https://doi.org/10.1212/01.wnl.0000436620.33155.a4

Angelelli, C.V. (2016). Bilingualism and Multilingualism. In C.V. Angelelli \& B.J. Baer (Eds.), Researching Translation and Interpreting (pp. 168-176). London and New York: Routledge. https://doi.org/10.7202/1038692ar

Baker, C. \& Wright, W.E. (2017). Foundations of Bilingual Education and Bilingualism. $6^{\text {th }}$ edition. Bristol: Multilingual Matters. https://doi. org/10.1007/978-3-319-02258-1_2

Barnett, W.S., Yarosz, D., Thomas, J., Jung, K. \& Blanco, D. (2007). Two-way and Monolingual English Immersion in Preschool Education: An Experimental Comparison. Early Childhood Research Quarterly, 22, 277-293. https:// doi.org/10.1016/j.ecresq.2007.03.003

Bialystok, E. (2011). Coordination of executive functions in monolingual and bilingual children. Journal of Experimental Child Psychology, 110, 461468. https://doi.org/10.1016/j.jecp.2011.05.005

Bialystok, E. (2001). Bilingualism in development: Language, literacy, and cognition. New York: Cambridge University Press. https://doi.org/10.1017/ CBO9780511605963

Bialystok, E., Craik, F.I.M. \& Freedman, M. (2007). Bilingualism as a protection against the onset of symptoms of dementia. Neuropsychologia, 45, 459464. https://doi.org/10.1016/j.neuropsychologia.2006.10.009

Bialystok, E., Craik, F. I., Klein, R. \& Viswanathan, M. (2004). Bilingualism, aging, and cognitive control: Evidence from the Simon task. Psychology and aging, 19, 290-303. https://doi.org/10.1037/0882-7974.19.2.290

Bialystok, E. \& Senman, L. (2004). Executive Processes in Appearance-Reality Tasks: The Role of Inhibition of Attention and Symbolic Representation. Child Development, 75(2),562-579.https://doi.org/10.1111/j.1467-8624.2004.00693.x

ELIA Mon. I, pp. 235-370 DOI: http://dx.doi.org/10.12795/elia.mon.2019.i1.13 
Bordons, M. (2004). Hacia el reconocimiento internacional de las publicaciones científicas españolas. Revista Española de Cardiología, 57, 799- 802. https://doi.org/10.1016/S0300-8932(04)77198-5

Bordons, M. \& Zulueta, M. (1999). Evaluación de la actividad científica a través de indicadores bibliométricos. Revista Española de Cardiología, 52, 790800. https://doi.org/10.1016/S0300-8932(99)75008-6

Borrow, L. \& Markman-Pithers, L. (2016). Supporting Young Learners in the United States. Future of Children, 26(2), 159-183. https://doi.org/10.1353/ foc. 2016.0017

Broca, A. (2016). CLIL and non-CLIL: differences from the outset. ELT Journal, 70(3), 320-331. https://doi.org/10.1093/elt/ccw011

Bybee, E., Henderson, K. \& Hinojosa, R. (2014). An Overview of U.S. Bilingual Education: Historical Roots, Legal Battles, and Recent Trends. Texas Education Review, 2(2), 138-146.

Carlson, S.M. \& Meltzoff, A.N. (2008). Bilingual experience and executive functioning in your children. Developmental Science, 11, 282-298. https:// doi.org/10.1111/j.1467-7687.2008.00675.x

Christoffels, I.K., Kroll, J. F. \& Bajo, M.T. (2013). Introduction to Bilingualism and Cognitive Control. Frontiers in Psychology, 4, 199-201. https://doi. org/10.3389/fpsyg.2013.00199

Costa, A., Hernández, M. \& Sebastián-Gallés, N. (2008). Bilingualism aids conflict resolution: Evidence from the ANT task. Cognition, 106, 59-86. https://doi.org/10.1016/j.cognition.2006.12.013

Coyle, D., Hood, P. \& Marsh, D. (2010). CLIL. Content and Language Integrated Learning. Cambridge: Cambridge University Press.

Cummins, J. (1979). Cognitive/academic language proficiency, linguistic interdependence, the optimum age questions and some other matters. Working Papers on Bilingualism, 19, 198-203.

European Commission. (2012). "Eurobarometer: 98\% say language learning is good for their children, but tests highlight skills gap." http://europa.eu/ rapid/press-release_IP-12-679_en.htm?locale=FR

ELIA Mon. I, pp. 235-370ＤOI: http://dx.doi.org/10.12795/elia.mon.2019.i1.13 
European Commission (2004). Promoting language learning and linguistic diversity. An action plan 2004-06. http://www.saaic.sk/eu-label/doc/200406_en.pdf

Fernández, R. \& Halbach, A. (2011). Analysing the situation of teachers in the CAM bilingual project after four years of implementation. In Y. Ruiz de Zarobe, J.M. Sierra \& F. Gallardo del Puerto (Eds.), Content and Foreign Language Instructed Learning. Contributions to Multilingualism in European Contexts. Frankfurt: Peter Lang.

Flores, N. \& García, O. (2017). A Critical Review of Bilingual Education in the United States: From Basements and Pride to Boutiques and Profit. Annual Review of Applied Linguistics, 37, 14-29. https://doi.org/10.1017/ S0267190517000162

Gándara, P. \& Escamilla, K. (2017). Bilingual Education in the United States. In O. García, A. Lin \& S. May (Eds.), Bilingual and Multilingual Education. Switzerland: Springer International Publishing. https://doi. org/10.1007/978-3-319-02324-3_33-2

García, E.B. (2018). The classroom language context and English and Spanish vocabulary development among dual language learners attending Head Start. Early Childhood Research Quarterly, 42(1), 148-157. https://doi. org/10.1016/j.ecresq.2017.09.005

García, O. (2009). Bilingual Education in the $21^{\text {st }}$ Century. A Global Perspective. Malden, MA: Wiley-Blackwell.

Genesee, F. (1987). Learning Through Two Languages: Studies of Immersion and Bilingual Education. Cambridge, MA: Newbury House.

Genesee, F., Lindholm-Leary, K., Saunders, W. \& Christian, D. (2006). Educating English learners: A synthesis of research evidence. Cambridge: Cambridge University Press. https://doi.org/10.1017/CBO9780511499913

Genesee, F., Lambert, W.E. \& Holobow, V. (1986). La adquisición de una segunda lengua mediante inmersión: el enfoque canadiense. Infancia y aprendizaje, 33, 27-36. https://doi.org/10.1080/02103702.1986.10822103

Glänzel W. \& Moed, H. (2002). Journal impact measures in bibliometric research. Scientometrics, 53, 171-193. https://doi.org/10.1023/A:1014848323806

ELIA Mon. I, pp. 235-370 DOI: http://dx.doi.org/10.12795/elia.mon.2019.i1.13 
Goldenberg, C. (2008). Teaching English language learners: What the research does - and does not— Say. American Educator. ESED 5234.

González Alcaide, G., Aleixandre Benavent, R. Navarro Molina, C. \& Valderrama Zurián, J.C. (2008). "Coauthorship networks and institutional collaboration patterns in reproductive biology." Fertil Steril, 90(4), 941-56. https://doi. org/10.1016/j.fertnstert.2007.07.1378

Grosjean, F. (2010). Bilingual: life and reality. Harvard: Harvard University Press. https://doi.org/10.4159/9780674056459

Halbach, A. (2008). Bilingual Methodology in Primary Schools. Revista de educación, 346, 455-466.

Halsall, N. (1998). French immersion: The success story told by research. Edmonton, AB: Alberta School Boards Association for Bilingual Education.

Holobow, N.E., Genesee, F. Lambert, W.E. \& Gastright, J. (1987). Effectiveness of partial French immersion for children from different social class and ethnic backgrounds. Applied Psycholinguistics, 8(2), 137-152.

Howard, E.R., Christian, D. \& Genesee, F. (2004). The Development of Bilingualism and Biliteracy from Grade 3 to 5: A Summary of Findings from the CAL/CREDE Study of Two-way Immersion. Santa Cruz, CA: CREDE, University of California at Santa Cruz.

Jäppinen, A.K. (2005). Thinking and Content Learning of Mathematics and Science as Cognitional Development in Content and Language Integrated Learning (CLIL): Teaching Through a Foreign Language in Finland. Language and Education, 19(2), 148-169. https://doi. org/10.1080/09500780508668671

Jiménez Catalán, R.M. \& Agustín Llach, M.P. (2017). "CLIL or time? Lexical profiles of CLIL and non-CLIL EFL learners.” System, 66, 87-99.

Jiménez Catalán, R.M., Ruiz de Zarobe, Y. \& Cenoz, J. (2006). Vocabulary profiles of English foreign language learners in English as a subject and as a vehicular language. Vienna English Working Papers (Views), 15(3), 23-27. https://doi.org/10.1016/j.system.2017.03.016

ELIA Mon. I, pp. 235-370 DOI: http://dx.doi.org/10.12795/elia.mon.2019.i1.13 
Kovács, A.M. (2009). Early bilingualism enhances mechanisms of false-belief reasoning. Developmental Science, 12(1), 48-54. https://doi.org/10.1111/ j.1467-7687.2008.00742.x

Lapkin, S., Swain, M. \& Shapson, S. (1990). French immersion research agenda for the 90s. The Canadian Modern Language Review, 46(4), 638-674. https://doi.org/10.3138/cmlr.46.4.638

Lasagabaster, D. \& López Beloqui, R. (2015). The Impact of Type of Approach (CLIL Versus EFL) and Methodology (Book-Based Versus Project Work) on Motivation. Porta Linguarum, 23, 41-57.

Lindholm-Leary, K.J. (2005). Review of Research and Best Practices on Effective Features of Dual Language Education Programs. Unpublished doctoral dissertation, San José State University.

Lorenzo, F., Casal, S. \& Moore, P. (2009). The effects of Content and Language Integrated Learning in European Education: Key Findings from the Andalusian Bilingual Sections Evaluation Project. Applied Linguistics, 31(3), 1-25. https://doi.org/10.1093/applin/amp041

Marsh, D. (2002). CLIL/EMILE $3 / 4$ The European Dimension: Actions, trends and Foresight Potential. Public Services Contract DG EAC. Strasbourg: European Commission.

Martín del Pozo, M.A. (2011). Teacher Training for CLIL in Higher Education: A Needs Analysis from a Language Awareness Perspective. Paper presented at the II Congreso Internacional de Enseñanza Bilingüe en Centros Educativos. Madrid: Universidad Rey Juan Carlos.

Mechelli, A., Crinion, J.T., Noppeney, V. O’Doherty, J. Ashburner, J. Frackowiak, R.S. \& Price, C.J. (2004). Neurolinguistics: Structural Plasticity in the Bilingual Brain. Nature, 431, 757. https://doi.org/10.1038/431757a

Merino, J. A. \& Lasagabaster, D. (2018). "CLIL as a way to multilingualism." International Journal of Bilingual Education and Bilingualism, 21(1), 7992. https://doi.org/10.1080/13670050.2015.1128386

Merisuo-Storm, T. (2007). Pupils attitudes towards foreign-language learning and the development of literacy skills in bilingual education. Teaching and Teacher Education, 23(2), 226-235. https://doi.org/10.1016/j.tate.2006.04.024

ELIA Mon. I, pp. 235-370 DOI: http://dx.doi.org/10.12795/elia.mon.2019.i1.13 
Mewald, C. (2007). A comparison of oral foreign language performance of learners in CLIL and mainstream classes at lower secondary level in Lower Austria. In C. Dalton-Puffer, T. Nikula, \& U. Smit (Eds.), Empirical Perspectives on CLIL Classroom Discourse (pp. 139-173). Amsterdam/Philadelphia: Peter Lang.

Molina, L. (2001). El análisis de redes sociales: una introducción. Barcelona: Editorial Bellaterra.

Okubo, Y. (1997). Bibliometric indicators and analysis of research systems: methods and examples. Working Papers Series of the OECD Directorate for Science, Technology and Industry.

Pavón Vázquez, V. \& Rubio, F. (2010). Teachers' Concerns and Uncertainties about the Introduction of CLIL Programs. Porta Linguarum, 14, 45-58.

Pena Díaz, C. \& Porto Requejo, M.D. (2008). Teacher Beliefs in a CLIL Education Project."Porta Linguarum, 10, 151-161.

Pérez Cañado, M.L. (2018). CLIL and Educational Level: A Longitudinal Study on the Impact of CLIL on Language Outcomes. Porta Linguarum, 29, $51-70$.

Pérez Cañado, M.L. (2017). CLIL Teacher Education. Where do we stand and where do we need to go? In $\mathrm{M}^{\mathrm{a}} \mathrm{E}$. Gómez Parra \& R. Johnstone (Eds.), Bilingual Education: educational trends and key competences. Ministerio de Educación, Cultura y Deporte.

Pérez Cañado, M.L. (2016). Teacher training needs for bilingual education: inservice teacher perceptions. International Journal of Bilingual Education and Bilingualism, 19(3), 266-295. https://doi.org/10.1080/13670050.201 4.980778

Petitto, L.A. (2009). New Discoveries from the Bilingual Brain and Mind Across the Life Span. Implications for Education. International Journal of Mind, Brain and Education, 3(4), 185-197. https://doi. org/10.1111/j.1751-228X.2009.01069.x

Poulin-Dubois, D., Blaye, A., Coutya, J. \& Bialystok, E. (2011). The effects of bilingualism on toddlers' executive functioning. Journal of Experimental ChildPsychology, 108,567-579.https://doi.org/10.1016/j.jecp.2010.10.009

ELIA Mon. I, pp. 235-370 DOI: http://dx.doi.org/10.12795/elia.mon.2019.i1.13 
Rubio Mostacero, M.D. (2009). Language Teacher Training for Non-Language Teachers: Meeting the Needs of Andalusian Teachers for School Plurilingualism Projects. Design of a Targeted Training Course. Jaén: Universidad de Jaén.

Salomone, R. (2010). True American: Language, Identity, and the Education of Immigrant Children. Cambridge, MA: Harvard University Press. https:// doi.org/10.4159/9780674056831

Sancho, R. (1990). Indicadores bibliométricos utilizados en la evaluación de la ciencia y la tecnología. Revisión bibliográfica. Revista Española de Documentación Científica, 13(3-4), 842-865.

Serra, C. (2007). Assessing CLIL in primary school: a longitudinal study. International Journal of Bilingual Education and Bilingualism, 10(5), 582602. https://doi.org/10.2167/beb461.0

Siegal, M., Iozzi, L. \& Surian, L. (2009). Bilingualism and conversational understanding in young children. Cognition, 110(1), 115-122. https://doi. org/10.1016/j.cognition.2008.11.002

Snow, M.A. (1998). Trends and issues in content-based instruction. Annual Review of Applied Linguistics, 18, 243-267. https://doi.org/10.1017/ S0267190500003573

Spies, T.G., Lara-Alecio, R., Tong, F., Irby, B.J., Garzam T. \& Huerta, M. (2018). The effects of developing English language and literacy on Spanish reading comprehension. The Journal of Education Research, 111(5), 517-529. https://doi.org/10.1080/00220671.2017.1306686

Stryker, S.B., \&. Leaver, B.L. (1997) (Eds.). Content-based Instruction in Foreign Language Education: Models and Methods. Washington: Georgetown University Press.

Swain, M. \& Lapkin, S. (1981). Bilingual education in Ontario: A decade of research. Toronto: Ontario Institute for Studies in Education.

Sylvén, L. K., \& Ohlander, S. (2014). The CLISS Project: Receptive Vocabulary in CLIL versus non-CLIL Groups. Moderna Sprak, 2, 80-108.

Thomas, W.P. \& Collier, V.P. (2002). A National Study of School Effectiveness for Language Minority Students' Long-term Academic Achievements. Center

ELIA Mon. I, pp. 235-370ＤOI: http://dx.doi.org/10.12795/elia.mon.2019.i1.13 
for Research on Education, Diversity and Excellence. http://www. thomasandcollier.com/assets/2002_thomas-and-collier_2002-final-report. pdf

Tragant, E., Marsol, A., Serrano, R. \& Llanes, A. (2016). Vocabulary learning at primary school: a comparison of EFL and CLIL. International Journal of Bilingual Education and Bilingualism, 19(5), 579-591. https://doi.org/10. 1080/13670050.2015.1035227

Turnbull, M., Hart, D. \& Lapkin, S. (2003). Grade 6 French immersion students' performance on large-scale reading, writing, and mathematics tests: Building explanations. Alberta Journal of Educational Research, 49(1): 6-23.

Turnbull, M., Lapkin, S. \& Hart, D. (2001). Grade 3 immersion students' performance in literacy and mathematics: Province-wide results from Ontario (1998-99). The Canadian Modern Language Review, 58(1), 9-26. https://doi.org/10.3138/cmlr.58.1.9

Umansky, I. \& Readon, S. (2014). Reclassification Patterns Among Latino English Learner Students in Bilingual, Dual Immersion, and English Immersion Classrooms. American Educational Research Journal, 51(5): 879-912. https://doi.org/10.3102/0002831214545110

Van de Craen, P., Ceuleers, E. \& Mondt, K. (2007). Cognitive development and bilingualism in primary schools: teaching math in a CLIL environment. In D. Marsh \& D. Wolff(Eds), Diverse Contexts - Converging Goals. CLIL in Europe (pp. 185-200). Frankfurt: Peter Lang.

Van Doorslaer, L. (2016). "Bibliometric Studies". In C.V. Angelelli \& B.J. Baer (Eds.), Researching Translation and Interpreting. London and New York: Routledge.

Verde-Peleato, I. (2011). Bilingual Education in the United States of America. Case studies of an Elementary School. Estudios sobre Educación, 21(21), 139-158.

Wesche, M. (2002). Early French immersion: how has the original Canadian model stood the test of time? In P. Burmeister, T. Piske, and A. Rohde (Eds.), An Integrated View of Language Development: Papers in Honour of Henning Wode (pp. 357-379). Wissenschaflicher Verlag Traer.

ELIA Mon. I, pp. 235-370 DOI: http://dx.doi.org/10.12795/elia.mon.2019.i1.13 
Zulueta, M.A. (2002). Bibliometría y métodos bibliométricos. In J. López Yepes (Eds.), Manual de Ciencias de la Documentación (pp. 117-136). Madrid: Pirámide.

First version received: July, 2019 Final version accepted: November, 2019 